\title{
PEMIMPIN DAN MEDIA: MISI PEMIMPIN MEMBAWA INJIL MELALUI DUNIA DIGITAL ${ }^{1}$
}

\author{
Daniel Ronda ${ }^{1)^{*}}$ \\ 1) Dosen Pascasarjana Program Doktor Teologi Sekolah Tinggi Theologia Jaffray \\ ${ }^{*}$ Penulis korespondensi: daniel.ronda@sttjaffray.ac.id
}

\begin{abstract}
Abstrak
Pemimpin di dunia digital berbicara tentang kesiapan memasuki media yang baru dengan pesan yang sama yaitu membawa nilai-nilai kekekalan firman Tuhan kepada manusia. Dunia tidak bisa lagi dipisahkan antara dunia nyata dan dunia digital. Itu sebabnya seharusnya pemimpin tidak lagi menyebut dunia digital sebagai dunia maya karena itu berarti sesuatu yang tidak nyata lagi. Revolusi komunikasi seperti ini mewajibkan pemimpin untuk mengambil tindakan drastis dalam melaksanakan pelayanan gereja dan mulai memberikan perhatian dan tenaga yang serius di dunia digital. Pelayanan di dunia digital sama nyatanya dengan pelayanan di dunia sehari-hari maka gunakan semua bentuk media untuk menyebarkan nilai-nilai kekekalan

Kata kunci: komunikasi, media, pemimpin, pelayanan, penginjilan, kekekalan, Tuhan, Kristen, medsos, internet

Leaders of the digital world are talking about the readiness to enter new media venues with the same message, that is to bring eternal values from the Word of God to mankind. The world can no longer be separated between the real world and the digital world. Because of that, leaders should no longer call the digital world "a virtual world" because it means something that isn't a reality anymore. A revolution of communication like this requires leaders to take drastic measures in the carrying out of their church ministry and begin to give serious attention and energy to the digital world. Ministry in the digital world is the same, in reality, as ministry in the everyday world that uses all forms of media to spread eternal values.
\end{abstract}

Key words: communication, leader, ministry, evangelism, eternity, Lord, Christian, social media, internet

\section{Pendahuluan}

Pemimpin Kristen harus menyadari bahwa dunia saat ini adalah dunia digital. Selama kurang dari tiga dekade dunia telah mengalami perubahan yang sangat drastis yaitu bagaimana manusia berkomunikasi. Perubahan itu meliputi teknologi informasi, hiburan, sains pengetahuan

\footnotetext{
${ }^{1}$ Disampaikan pada Orasi Ilmiah Rapat Terbuka Senat Sekolah Tinggi Theologia Jaffray Wisuda Sarjana ke-42 tanggal 17 September 2016 di Makassar.
} 
dan pergaulan serta cara berkomunitas atau bersosialisasi. Bahkan perkembangannya masih dalam proses yang terus berubah dan belum diketahui ke mana ujungnya mengingat berkembangan teknologi yang tidak terbatas ini. Tentu kepedulian pemimpin Kristen terhadap teknologi bukan karena faktor ikut-ikutan tren yang sedang berkembang atau karena tidak mau disebut ke-tinggalan zaman, tetapi pemimpin perlu berfokus kepada bagaimana perintah Amanat Agung disampaikan ke dalam dunia digital ini. Di mana manusia berkumpul dan bersosialisasi, di sanalah pemimpin Kristen juga ada dalam memberitakan nilai-nilai kekekalan.

Ada masalah yang diangkat dalam tulisan ini yaitu tentang pemimpin dan media di dunia digital ini.

Pertama, masalahnya adalah bahwa dunia digital belum diketahui beberapa generasi sebelumnya tapi saat ini telah menjadi hal paling mendasar atau paling esensial dalam kehidupan. Dunia hari-hari ini telah dikuasai oleh komputer pribadi, internet, media sosial dan telepon genggam pintar (smart phone) di mana semua interaksi sosial sudah berpindah dari interaksi langsung menjadi interaksi di dunia digital atau disebut dengan dunia maya. Belum ada era sebelumnya seperti zaman ini yang paling dahsyat perubahan dalam berkomunikasi. Ini menjadi kejutan budaya bagi pemimpin yang usianya di atas 30 tahun saat ini, sehingga ada kesenjangan pendekatan dunia digital antara generasi tua dan generasi mudanya. ${ }^{2}$

Kedua, masalah lain adalah banyak pemimpin Kristen yang sibuk melakukan pelayanan di dunia nyata secara setia tetapi tidak peduli kepada dunia digital. Pemimpin yang demikian telah melakukan kesalahan yang fatal. Pelayanan tatap muka dan percakapan dianggap lebih berarti dan lebih nyata, sebenarnya dunia digital itu pun nyata tetapi dalam kenyataan yang bentuknya berbeda. Dengan kata lain pemimpin belum siap dalam menghadapi perubahan pola pelayanan, yang mana komunikasi telah menjadikan teknologi komputer dan dunia digital menjadi media paling urgen dalam berkomunikasi. ${ }^{3}$

Padahal fakta yang dihadapi hari ini adalah bahwa komunikasi secara nyata itu ada dalam dunia digital, situs atau web, dan dalam telepon pintar di dalam genggaman manusia. Informasi yang nyata dibagikan dan secara global telah disebarluaskan lebih cepat dari

\footnotetext{
${ }^{2}$ Permasalahan ini diangkat oleh Rektor Southern Baptist Theological Seminary: Albert Mohler, "The Christian Leader in the Digital Age," diakses 1 Juli 2016, http:// www.albertmohler.com/2014/02/19/the-christian-leader-in-the-digital-age-2/

${ }^{3}$ Bacaan wajib bagi pemimpin Kristen adalah buku terjemahan yaitu Charles R. Berger (ed.), Handbook Ilmu Komunikasi (Bandung: Nusamedia, 2014).
} 
sebelumya. Percakapan nyata saat ini lewat suara, kata dan gambar, yang menghubungkan manusia di seluruh dunia.

Dalam tulisan ini mencoba mencari jawaban atas pergumulan menghadapi media dalam dunia digital ini. Jika pemimpin Kristen tidak menjadi orang yang terdepan dalam dunia digital, maka kepemimpinannya terbatas kepada orang-orang masa lalu dan tidak peduli kepada dunia yang berbeda di depan. Adalah suatu fakta bahwa orang yang tidak masuk di dunia digital makin lama makin berkurang dan mau tidak mau pemimpin berhadapan dengan dunia digital.

Tulisan ini akan menjelaskan apa itu dunia digital, bahaya dan berkat dunia digital, bagaimana mengembangkan pelayanan internet, dan bagaimana membawa Injil dan menanamkan nilai-nilai Kristiani di dunia digital ini.

\section{Bentuk Dunia Digital}

Dalam dunia digital ada beberapa bentuk (plattform) dan teknologi yang dipakai dalam berkomunikasi. Dalam tulisan ini terlebih dahulu dibahas tentang berbagai bentuk dunia digital yang ada sampai tahun 2016 ini: $^{4}$

Pertama, dunia menjadi digital memang dipengaruhi awalnya oleh dunia hiburan dan kaum ideologis yang ingin menghubungkan manusia di seluruh jagad raya ini. Ini dimulai dengan menculnya www atau the world wide web. Kemudian hal ini merambah ke semua bidang kehidupan manusia tanpa terkecuali. Sejak kurang dari dua puluh tahun lalu ketika internet www mulai muncul, saat ini sudah menghubungkan manusia sebanyak lebih dari dua milyar orang.

Kedua, perkembangan telepon genggam di mana saat ini ada 5,9 milyar orang mempunyai telepon genggam (Handphone atau disingkat HP) dan itu berarti ada $87 \%$ populasi dunia punya alat ini. Awalnya telepon genggam ini hanya berfungsi berbicara dan mengirim teks, lalu ditambah beberapa "games" dan permainan. Saat ini HP telah menjadi alat transaksi untuk semua bidang kehidupan mulai dari alat komunikasi, perbankan, bisnis, mendapatkan informasi, berita dan hiburan dan segala bentuk pengetahuan dan sains. Bahkan di negaranegara berkembang sekalipun termasuk Indonesia sudah menjamur telepon pintar ini. Ini fakta bahwa saat telepon lama yang hanya

\footnotetext{
${ }^{4}$ Sangat penting mengetahui sejarah perkembangan dunia digital sampai saat ini. Bahan sejarah perkembangan dunia digital dapat dilihat selengkapnya di tulisan Maryann G. Billington dan Peter J. Billington, "Social Media Tools for Leaders and Managers," Journal of Leadership, Accountability and Ethics 9, no. 6 (2012):11-19.
} 
berfungsi untuk menelpon dan mengirim SMS akan menjadi barang antik.

Ketiga, jurnalisme warga (citizen journalism) yang muncul dalam pembuatan blog adalah hal yang baru muncul 15 tahun yang lalu. Blog gratis yang terkenal seperti Wordpress atau blogspot adalah diminati untuk berinteraksi baik untuk berbagi ilmu, seni, hobi bahkan sampai bisnis. Saat ini pengguna blog itu diakses 300 juta orang dan jumlah blog yang ada sekitar 2,5 milyar halaman blog dan itu bertambah tiap harinya. Hari ini mesin pencari Google telah menjadi sumber segala-galanya bagi manusia. Untuk mencari makna kata tidak perlu ke kamus. Semua hal dapat dicari di Google mulai dari kesehatan, kehidupan pribadi, pendidikan, dan semua hal. Perpustakaan tradisional makin lama makin ditinggalkan terutama usia 30 tahun ke bawah. Semua informasi sudah tersedia di mesin pencari Google. Citizen journalism lalu berkembang saat ini sudah memakai media sosial yang akan dijelaskan di bawah.

Keempat adalah media sosial, di mana yang paling menghebohkan adalah Facebook dan Twitter. Ini dimulai dari seorang bernama Mark Zuckerberg di tahun 2004 dan saat ini sudah 1 milyar manusia terkoneksi dengan Facebook. Begitu juga dengan Twitter, Instagram, snapchat dan berbagai media sosial yang akan bermunculan terus menerus. Memang Twitter tidak begitu menggembirakan penggunanya di Indonesia tetapi di Amerika Twitter menjadi alat yang dipakai media tradisional untuk melakukan tweet berita dan informasi mereka. Media sosial ini sangat berperan sekali, bahkan ditakuti para pemimpin dunia karena dia memiliki kekuatan yang menggerakkan perubahan bahkan pemberontakan sekalipun. Wapres Jusuf Kalla mengatakan, "Dulu setiap pemberontakan pasti ada pemimpinnya. Namun hal itu kini berubah. Media sosial dianggap sebagai 'pemimpin' pemberontakan maupun konflik... Dunia sekarang boleh berontak. Dulu setiap konflik selalu ada pemimpin. Sekarang dunia revolusi tanpa pemimpin lagi. Yang Pimpin Facebook, SMS, WA (WhatsApp), media sosial, itu yang terjadi" ${ }^{5}$

Yang paling menggemparkan juga tentunya penggunaan YouTube yaitu mesin penyedia layanan video yang disiapkan oleh penggunanya dan dinikmati bersama dalam wadah YouTube. Semua yaitu segala jenis film video mulai dari hiburan sampai sains ada dalam YouTube. Anak muda sudah tidak asing lagi untuk mendapatkan informasi. YouTube merupakan mesin pencari video kedua yang digunakan manusia setelah

\footnotetext{
${ }^{5}$ Ray Jordan, "JK di Depan Perwira Polri: Pemberontakan Saat ini Dipimpin Facebook dan WA," diakses 29 Agustus 2016, http://www.news.detik.com/berita/3286112/jk-di-depan-perwira-polripemberontakan-saat-ini-dipimpin-Facebook-dan-wa.
} 
mesin pencari google. Semakin waktu semakin meningkat peranan YouTube dalam mengubah informasi ke yang lebih visual. ${ }^{6}$

Dunia digital itu masif sekali dan bersifat transformatif yaitu membawa perubahan. Media massa tradisional pun saat ini sudah menggunakan web atau situs internet, dan media sosial sudah merambah menggantikan telepon tradisional. Untuk menelpon orang sudah menggunakan Skype, Line, WhatsApps dan seterusnya. HP sudah menjadi komputer yang bisa menelepon dengan teknologi voice calls. Itu sebabnya membayar sms dan telepon akan menjadi barang langka dan diganti dengan cukup membayar internet data.

Maka dunia digital menjadi hutan rimba informasi dan diskusi/percakapan. Segalanya bisa ditemukan di internet hanya dengan mouse atau sentuhan layar lewat jari-jari. Semua dapat diakses mulai dari khotbah sampai pornografi, teroris, politik, hiburan dan banyak hal lainnya. Dari hal yang baik sampai hal-hal yang tidak baik sekalipun.

Internet dan teknologi digital telah menghubungkan manusia dan sekaligus pada saat yang sama memutuskan hubungan manusia. Ada istilah, dunia digital "mendekatkan yang jauh dan menjauhkan yang dekat" yaitu persekutuan dalam keluarga dan pertemanan di dunia nyata. Bahaya dengan melubernya informasi seperti ini adalah manusia memiliki daya perhatian yang sedikit atau kurang perhatian dan tidak dalam. Pada sisi lain media sosial membawa kepada demokratisasi dan bisa menembus daerah-daerah yang tidak bisa ditembus sebelumnya. Injil pun bisa masuk ke daerah-daerah yang dianggap tertutup.

Pada bagian lain, struktur sosial masyarakat diporakporandakan di mana anak remaja bisa lebih hebat dari seorang usia yang lebih tua. Bahkan mungkin blognya dibaca lebih banyak daripada orang yang menyebut dirinya profesor. Dalam perdebatan sudah tidak ada lagi mana orang tua dan mana yang lebih muda. Tidak ada penghargaan gelar dan status. Semua rintangan komunikasi tidak ada lagi. Ini kesaksian seorang hamba Tuhan yang justru bisa masuk dalam hubungan yang lebih dalam setelah menggunakan Twitter. Ron Edmonson bersaksi: "It seems harder to get to know people today. They are more guarded and less trusting. When I Tweet (which updates my Facebook), people get a glimpse into the real me and I become more personal to the people in my church and online community. In turn,

\footnotetext{
${ }^{6}$ Ambar Kusuma Ningrum, "YouTube Stickiness (Pengaruh Continuance Motivation dan Perilaku Berbagi terhadap YouTube Stickiness pada Mahasiswa Program Studi Ilmu Komunikasi S1 Reguler FISIP UNS Angkatan 2012-2014)," Skripsi, S.Sos, Universitas Sebelas Maret, 2016. Temuan skripsi menyatakan makin hari makin banyak orang yang bergantung dan mencari informasi dan hiburan di YouTube.
} 
people are more likely to allow me into the deepest parts of their life when they see me as authentic and approachable."

Risiko di dunia digital adalah bahwa semua informasi dalam internet belum dapat dipercaya karena opini yang dibuat seringkali tidak diedit dan opini sesukanya. Penekanan kepada temuan kecepatan dan bukan kepada akurasi berita sebagaimana halnya prinsip dasar menulis dalam media-media yang meliputi unsur $4 \mathrm{~W}+1 \mathrm{H}$ (What, Who, When, Where dan How). Mereka yang menulis di media sosial tidak memedulikan kebenaran namun kecepatan informasi. ${ }^{8}$

Jika ada yang belum terkoneksi dengan internet maka dianggap belum eksis (ada). Usia 30 tahun ke bawah disebut "digital natives", di mana mereka jarang menulis dan menerima surat. Informasi yang diterima bersifat instan, multitasking di mana mereka bisa melakukan sesuatu beberapa hal secara bersamaan, walaupun sedang duduk di kelas sekalipun.

Penjelasan di atas baru sebagian dari dunia digital karena memang dunia digital itu luas sekali dan kompleks, rumit dan meledak. Ada kekaguman dan horor di balik semua perkembangan yang hebat ini. Maka inilah masa bagi pemimpin untuk mengevaluasi diri karena dunia digital sudah tidak dapat lagi dihindari. Jika memimpin tanpa mengindahkan dunia digital maka pemimpin akan kehilangan efektivitasnya. Jika pemimpin ingin memengaruhi masa depan, maka pemimpin harus menghidupi dan merangkul dunia digital dan bukan sebaliknya malah menjauhinya.

\section{Pemimpin yang Mengembangkan Internet}

Saat ini banyak gereja, perusahaan, organisasi, sekolah sudah memiliki situs internet atau "page" media sosial. Mereka ini sadar bahwa tanpa internet mereka tidak akan eksis. Namun tidak sedikit juga semangat mengembangkan internet itu ada pada awalnya, namun tidak memiliki semangat untuk memeliharanya. Sebelum memikirkan betapa pentingnya dunia digital, maka perlu dipahami bagaimana dengan

\footnotetext{
${ }^{7}$ Ron Edmondson, "7 Reasons You Need Social Media as a Christian Leader", diakses 1 Juli 2016, https://www.idisciple.org/post/7-reasons-you-need-social-media-asa-christian-leader

${ }^{8}$ Lihat bahasan menarik dari Santi Dwi Jayanti, “Twitter Sebagai Bentuk Citizen Journalism Baru di Internet (Analisis Isi Kualitatif Pemberitaan Bencana Lahar Dingin dan Penampakan Halo Matahari di Akun Jogja Update di Situs Microblogging Twitter sebagai Media Citizen Journalism bagi Masyarakat Yogyakarta Periode 1 Januari 2011-5 Januari 2011)," Skripsi, S.Sos, UAJ Yogyakarta, 2011. Skripsi ini menemukan bahwa penggunaan media sosial lebih mementingkan kecepatan berita daripada keakuratan berita-berita tentang bencana yang terjadi di Yogyakarta.
} 
pengguna internet di Indonesia. Menurut data terbaru dari We Are Social, jumlah pengguna internet di dunia saat ini adalah 3,25 miliar. Angka ini naik dari yang tadinya 3,17 miliar menurut data sebelumnya pada bulan Agustus. Bagaimana dengan Indonesia? Dengan penetrasi 34 persen, kini pengguna internet di Indonesia mencapai 88,1 juta pengguna. 79 juta di antaranya merupakan pengguna media sosial aktif. Angka yang tidak mengherankan, mengingat Indonesia merupakan salah satu negara teraktif di media sosial. ${ }^{9}$

Menurut Pusat Kajian Komunikasi (Puskakom) UI dan APJII maka pengguna internet di Indonesia mencapai 88,1 juta dan bila dibandingkan dengan penduduk Indonesia yang 252 juta maka pengguna internet sudah mencapai $34 \%$ dari total penduduk. Dari pengguna internet ini, maka 85\% mengakes internet lewat telepon selular mereka dan baru sesudah itu dengan komputer PC dan Laptop. Alasan mereka menggunakan internet yang utama adalah karena memakai media sosial (Fb dan seterusnya) sebanyak 87\%, untuk mencari informasi dan mengunduh pengetahuan sebanyak $68,7 \%$, mencari berita terkini $59,7 \%$, mengunduh atau mengunggah video $27,3 \%$, berkomunikasi via surel (email) sebanyak $25,4 \%$ dan berbelanja online (e-commerce) sebanyak $11 \%$ yang menunjukkan bahwa orang Indonesia sudah banyak yang berbelanja lewat internet. ${ }^{10}$

Profil di atas membuktikan betapa pemimpin di Indonesia perlu mengembangkan layanan internet. Ada beberapa prinsip dasar menjadikan internet sebagai pelayanan:

Pertama, diperlukan ahli dalam bidangnya untuk menyusun situs internet, di mana internet yang menarik untuk dikunjungi dan isinya dibaca oleh pembaca. Isi berita adalah segala-galanya. Orang mencari blog karena membutuhkan informasi. Harus ada komitmen dan secara reguler mengembangkannya. Itu sebabnya menyiapkan isi berita juga tidak kalah pentingnya dalam dunia digital. Maka pemimpin harus membuktikan diri mampu melakukan pelayanan menulis sebagai bagian yang tak terpisahkan dalam pelayanan dunia digital. Ketika zaman ini dengan mudahnya orang melakukan plagiasi atau dikenal dengan istilah "copy-paste", maka pemimpin harus memiliki integritas dalam menyusun bahan dan menyebutkan sumber-sumber tulisan jika harus mengambil bahan orang lain.

\footnotetext{
9 "Statistik Pengguna Internet dan Media Sosial Terbaru di Indonesia," diakses 6 September 2016, https://id.techinasia.com/talk/statistik-pengguna-internet-dan-mediasosial-terbaru-di-indonesia.

10 "Profil Pengguna Internet di Indonesia 2015" bersumber dari Puskakom UI dan APJII sebagaimana dikutip dalam Berita Oikumene (Juli-Agustus 2016), 33.
} 
Kedua, pemimpin sendiri harus memiliki blog sendiri untuk mengetahui siapa Anda dan bagaimana cara berpikir Anda, misi Anda, dan membangun kepercayaan dan integritas. Pemimpin tidak boleh lagi menjadi penerima bahan-bahan dalam internet, tapi mereka harus berkontribusi memberikan materi-materi yang membawa kepada nilainilai kebaikan, etika kemanusiaan, pemeliharaan lingkungan hidup dan hubungan yang akrab dengan Tuhan.

Ketiga, pentingnya berita untuk dikomunikasikan dengan berbagai cara. Tetapi pemimpin dalam dunia digital harus menyadari bahwa zaman ini adalah zaman naratif (cerita), di mana manusia menikmati jalan cerita sebagai drama kehidupan (storytelling). Bila dunia dapat dibagi menjadi tiga bagian, maka ada dinamakan Pre-Gutenberg di mana manusia berkomunikasi lewat oral yaitu menggunakan mulut untuk mengajar dan berkomukasi lewat cerita. Lalu masuk abad ke-16 sebagai era Gutenberg di mana dikembangkan budaya menulis dan meledaknya pendekatan sains untuk membuktikan kebenaran. Maka abad ke-2l ini disebut abad Post-Gutenberg atau disebut Digitoral Era, di mana kembali ke dunia oral yang mengutamakan cerita tapi memakai teknologi digital yaitu berbagai media sosial baik Facebook, Twitter, Instagram, dan seterusnya. Maka cerita itu sudah tidak mengikuti kaidah logika dan cara berpikir ilmiah. Semua sudah tidak berbentuk dan disebarkan oleh siapa saja. Ini masa di mana cerita-cerita itu sangat diperhatikan dan mendapat tempat dalam kehidupan manusia. ${ }^{11}$ Maka pemimpin harus menjadi orang yang mampu bercerita dan mengekspresikan cerita itu dalam tulisan untuk menyatakan nilai-nilai kehidupan dan kekekalan.

\section{Misi Pemimpin Membawa Injil Lewat Dunia Digital}

Gereja pada sisi lain harus tetap mengerti bahwa hakikat keberadaannya adalah untuk memberitakan Injil, membawa Kristus kepada dunia dan menjadikan segala bangsa murid-Nya. Gereja sudah melaksanakan itu selama 2000 tahun dan saat ini gereja harus menghadapi generasi yang baru yaitu generasi digital, sehingga perlu melaksanakan tugas Amanat Agung di dalam dunia digital ini. Hari ini revolusi digital sudah di depan mata di mana telah tersedianya alat, kesempatan dan bentuk yang mempemudah Injil masuk kepada generasi ini. Ada beberapa hal praktis yang perlu dilakukan pemimpin dalam menghadapi dunia digital:

\footnotetext{
${ }^{11}$ Samuel Chiang, "Post Gutenberg! Oral Preference Learners Welcome the
}

Digitoral Era," diakses 7 September 2016,

http://www.missionfrontiers.org/issue/article/post-gutenberg 
Pertama, pemimpin Kristen harus mengambil keuntungan dari perkembangan dunia digital dengan memanfaatkan blog (blog berbayar atau pun yang gratis), media sosial baik Facebook, Twitter, Instagram, YouTube dan semua bentuk komunikasi yang tersedia untuk menyampaikan maksud Tuhan. Pemimpin gereja harus secara sengaja menyediakan diri dan dana untuk belajar mengembangkan pelayanan online yang mana kesempatan ini sudah terbuka dan tidak ada batasnya lagi.

Kedua, pada waktu yang sama, pemimpin Kristen harus menyadari bahaya dan godaan dari dunia digital, harus disadari bahwa dunia digital bisa dipakai untuk kebaikan dan sekaligus untuk kejahatan. Untuk itu pemimpin Kristen harus memberikan pengaruh lewat dunia digital, karena pengaruh itu tersebar dengan masif lewat tulisan dan pemikiran yang dibagikan. ${ }^{12}$

Ketiga, harus diingat bahwa kepemimpinan Kristen bukan berbicara soal teknologi, karena teknologi itu berkembang dan tidak ada batasnya. Bukan fokus kepada teknologi, tapi kepada perintah untuk memberitakan Injil. Tujuan keterlibatan di dunia digital untuk membawa Injil, membawa nilai-nilai kekristenan yang me-mengaruhi dunia. Tugas pemimpin untuk menjadi garam dan terang dalam dunia yang penuh kegelapan yaitu nilai-nilai yang begitu absurd.

\section{Kesimpulan}

Pemimpin di dunia digital berbicara tentang kesiapan memasuki media yang baru dengan pesan yang sama yaitu membawa nilai-nilai kekekalan firman Tuhan kepada manusia. Tulisan ini diharapkan dapat meyakinkan semua pemimpin bahwa masuk ke dalam dunia digital adalah keniscayaan. Dunia tidak bisa lagi dipisahkan antara dunia nyata dan dunia digital. Itu sebabnya seharusnya pemimpin tidak lagi menyebut dunia digital sebagai dunia maya karena itu berarti sesuatu yang tidak nyata lagi. Revolusi komunikasi seperti ini mewajibkan pemimpin untuk mengambil tindakan drastis dalam melaksanakan pelayanan gereja dan mulai memberikan perhatian dan tenaga yang serius di dunia digital. Sudah waktunya ini mendapat perhatian serius dari para pemimpin sehingga tetap efektif dan relevan di dalam dunia digital ini.

\footnotetext{
${ }^{12}$ Lihat selengkapnya tulisan Ed Stetzer, "3 Ways Social Media Benefits Church Leaders," diakses 1 Juli 2016, http://www.christianitytoday.com/edstetzer/2015/february/3-ways-social-mediabenefits-church-leaders.html.
} 


\section{Kepustakaan}

Berger, Charles R. Ed. Handbook Ilmu Komunikasi. Bandung: Nusamedia, 2014.

Billington, Maryann G. dan Peter J. Billington, "Social Media Tools for Leaders and Managers." Journal of Leadership, Accountability and Ethics 9, no. 6 (2012):11-19.

Chiang, Samuel. "Post Gutenberg! Oral Preference Learners Welcome the Digitoral Era." Diakses 7 September 2016, http://www.missionfrontiers.org/issue/article/post-gutenberg Edmondson, Ron. "7 Reasons You Need Social Media as a Christian Leader", diakses 1 Juli 2016, https://www.idisciple.org/post/7reasons-you-need-social-media-as-a-christian-leader Jayanti, Santi Dwi. "Twitter Sebagai Bentuk Citizen Journalism Baru di Internet (Analisis Isi Kualitatif Pemberitaan Bencana Lahar Dingin dan Penampakan Halo Matahari di Akun Jogja Update di Situs Microblogging Twitter sebagai Media Citizen Journalism bagi Masyarakat Yogyakarta Periode l Januari 2011-5 Januari 2011)," Skripsi S.Sos, UAJ Yogyakarta, 2011.

Jordan, Ray. "JK di Depan Perwira Polri: Pemberontakan Saat ini Dipimpin Facebook dan WA." Diakses 29 Agustus 2016. http://www.news.detik.com/berita/3286112/jk-di-depan-perwirapolri-pemberontakan-saat-ini-dipimpin-Facebook-dan-wa

Mohler, Albert. "The Christian Leader in the Digital Age." Diakses 1 Juli 2016. http:// www.albertmohler.com/2014/02/19/the-christianleader-in-the-digital-age-2/

Ningrum, Ambar Kusuma. "YouTube Stickiness (Pengaruh Continuance Motivation dan Perilaku Berbagi terhadap YouTube Stickiness pada Mahasiswa Program Studi Ilmu Komunikasi S1 Reguler FISIP UNS Angkatan 2012-2014)." Skripsi S.Sos, Universitas Sebelas Maret, 2016.

"Profil Pengguna Internet di Indonesia 2015" Berita Oikumene. Juli-Agustus 2016.

"Statistik Pengguna Internet dan Media Sosial Terbaru di Indonesia." Diakses 6 September 2016. https:/id.techinasia.com/talk/statistikpengguna-internet-dan-media-sosial-terbaru-di-indonesia

Stetzer, Ed. "3 Ways Social Media Benefits Church Leaders." Diakses 1 Juli 2016.

http://www.christianitytoday.com/edstetzer/2015/february/3-wayssocial-media-benefits-church-leaders.html. 